\title{
Arranging Street Vendors A Study on Policy Management of Street Vendors in Bandung
}

\author{
Rina Hermawati \\ Department of Anthropology \\ University of Padjadjaran \\ Bandung, Indonesia \\ rina.antrop@gmail.com
}

\author{
Caroline Paskarina \\ Department of Politics Science \\ University of Padjadjaran \\ Bandung, Indonesia \\ caroline.paskarina@unpad.ac.id
}

\begin{abstract}
The policy paradigm shift of the order into structuring has not significantly solved the problem of street vendors in Bandung. This condition could not be separated from the formulation of policies that tend to top down and only involve the organization of street vendors as a condition of policy-making formality. In addition, the quality and quantity of the policy implementing apparatus do not have sufficient capacity to implement policies on structuring street vendors. The limitation of relocation place becomes a challenge for the Bandung City government. Bandung City Government is required to exploit markets and lands that are not used as a relocation of street vendors or to create innovation in making new space for street vendors.
\end{abstract}

Keywords: policy management; relocation; street vendors; Bandung

\section{INTRODUCTION}

The city government's policy on street vendors is inseparable from the dilemma faced by the city government in addressing the problem of street vendors. On one side, the presence of street vendors is considered as the "savior" because it provides employment, facilitates consumers in obtaining cheap goods, makes the city more attractive, and enlivens the city. On the other side, street vendors are considered to be one of the causes of traffic jam and also, they are considered to be the disturbance to the city's cleanliness and beauty. This dilemma allegedly has caused the city government to be slow and inconsistent in implementing the policy on street vendors.

The view that places street vendors as the disturbance causing the city's dirtiness and disorder has made the policy on street vendors before 2011 dominated by the policy of eviction. The policy of eviction cannot be implemented consistently, among other things, because of street vendors' resistance. After the 1998 reform which is marked by a more open political structure of Indonesia and the failure of the policy on street vendors due to street vendors' resistance to the policy, the government changed the paradigm of the city government in settling the problem of street vendors [1]. In Bandung, the paradigm has been embodied in Local By Law Number 4 Year 2011 on Supervision and Arrangement of Street Vendors which in outline contains the spatial arrangement of street vendors, the organization of policy

Corresponding authors: Rina Hermawati implementers, a limitation on the number of street vendors, the approach of consumers' behavior. Normatively, the policy on street vendors seems to be ideal. However, the reality in the field indicates that the policy cannot be optimally realized. This article would explain the implementation problem of the policy on street vendors. By using a perspective on the policy theory, the writer attempted to describe the internal and external factors which made the implementation of the policy on the arrangement of street vendors have not been optimum.

\section{RESEARCH METHOD}

This research used the qualitative method in order to be able to holistically describe the management of street vendors in Bandung. The data collection techniques were conducted through in-depth interviews, participant observation, and documentation. Interviews were conducted with board members of the associations/organizations of street vendors, and the Special Task Force of Street Vendors in Bandung. In order to select informants from the organizations of street vendors, the writer conducted a preliminary survey by spreading questionnaires to the organizations. These questionnaires were able to map the strengths of the organization of street vendors as the basis in selecting the research informants. Meanwhile, informants from the Special Task Force of Street Vendors included the government apparatus who directly addressed the problem of street vendors, such as the Civil Service Police Unit, the Office of Cooperatives, Small and Medium-sized Enterprises, and Industry and Trade, and Regional Development Planning Agency. Participatory observation was conducted to find out directly the trading activities of street vendors, the atmosphere and interaction they built. During the activities of participatory observation, the researchers closely observed what they did, when, and with whom, in what condition, and asked them about their action. Meanwhile, documentation materials used in this research particularly related to characteristics and distribution of street vendors, organization of street vendors, and activities of the city government in handling street vendors. These documents were obtained through Civil Service Police Unit, the Office of Cooperatives, Small and Medium-Sized Enterprises, and Industry and Trade, and Local Development Planning Agency, association of street vendors, the Internet, blog, photos, videos, and other references. 


\section{RESULT AND DISCUSSION}

The policy on the arrangement of street vendors in Bandung City includes, among other things, zonation of street vendors, characteristics and classification of street vendors, the Special Task Force, and Identity Cards.

1. Zonation of Street Vendors: Spatial Arrangement of Street Vendors in Bandung City

The arrangement of street vendors in Bandung City appears more clearly in a spatial way, in which Bandung City divides its space based on zones, namely a location which has a certain function based on place and time for the arrangement of street vendors. For the arrangement of street vendors Bandung City divides its space into 3 zones as follows: 1) Red Zone is locations in Bandung City where sidewalk vendors are forbidden to operate; 2) Yellow Zone is locations which can be opened and closed for the operation of sidewalk vendors based on time and places; and 3) Green Zone is locations where sidewalk vendors are allowed to operate by using five concepts of arrangements, namely:

a. Relocation; the process of moving places for street vendors to sell goods,

b. Market revitalization; the improvement of the function and potential of markets based on the utilization of land of the market unused by street vendors,

c. Thematic shopping; the placement of street vendors based on types of wares at a certain location,

d. Concept of Festival; the placement of street vendors based on the organization of certain events, and

e. Concept of Pujasera (Snack Food Centre); the placement of street vendors that sell foods at certain locations based on the profit-sharing system with the owners of locations as substitute for the rent.

2. Characteristics and Classification of Street Vendors

The policy on the arrangement of street vendors regulates their characteristics, in which they use equipment that can be easily disassembled or moved for selling their wares and also, they use part of roads sidewalks, and/or other public places which actually are not allocated for permanent trading places. Equipment they use for selling goods includes food tents, push carts, or mats spread out on the ground. Meanwhile, kinds of wares they sell are foods and beverages, clothes/textile, children's toys, small goods, vegetables and fruit, drugs, printed matters, personal services, and secondhand appliances. Provisions on characteristics and classifications of street vendors are regulated to respond to the condition since 2008 when "modern street vendors" sprang up, for example, street vendors who use cars for selling wares and street vendors who are actually employees/workers of the formal sector but they sell wares in the street on consignment.

\section{The Special Task Force: Integrative Arrangement of Street Vendors}

Significant obstruction to the implementation of By law on public order, cleanliness, and beauty (K3) is the lack of clarity of the agencies which have the authority to deal with street vendors. Up to now street vendors are handled only by Civil Service Police Unit that prioritizes the eviction approach. With a paradigm shift on street vendors, they must be approached from the other factor in the form of arrangement and supervision by involving cross-sectoral agencies. Therefore, the Special Task Force (Satgasus) has been established, with the task to assist the Mayor in implementing the arrangement and supervision of street vendors, which include planning, arranging, supervising, watching, controlling, and law enforcement.

4. Identity Cards of Street Vendors: Limitation of the Number of Street Vendors

In order to be allowed to operate all street vendors must have the identity card issued by the Mayor and delegated to the Office of Cooperatives, Small and Medium-Sized Enterprises, and Industry and Trade. This identity card is given only to street vendors who have resident's identity card of Bandung City, have lived in Bandung for at least 5 years, and operate at the Green Zone.

5. Fines Imposed on Purchasers: Arrangement of Street Vendors with the Approach of Consumers' Behavior

The success of the arrangement of street vendors by the city government demands the public's participation as the consumers of the products sold by street vendors. One of the forms of participation is by not buying goods in the locations forbidden for street vendors. As long there are purchasers, street vendors will not hesitant to sell of their wares both openly and secretly. Therefore, the city government has made some efforts to cut the links between consumers and street vendors by imposing fines to consumers who purchase goods from street vendors in the Yellow and Red Zones.

In general, street vendors' responses to the policy of arrangement are divided into two groups, i.e. accepting on certain conditions and refusing the policy. The group that accept the policy on certain conditions think that the arrangement of street vendors can be conducted by considering the suitability of the places of relocation with characteristics of street vendors and its integration with the policy of supervision, such as facilitation of loans, the improvement of the business ability of street vendors, and the promotion of places of relocation. Meanwhile, the other group refuses the arrangement of street vendors because they have lost their confidence in the government's ability in resolving the problem street vendors. This distrust has made the organizations of street vendors make every effort to oppose the policy, both in the form of resistance and negotiation with the government apparatus. The rejection of street vendor policy is also because street vendors are not involved fully in the process of policy formulation. The involvement of street vendors is represented by the organization only on the aspect of formal requirements in policy formulation. Meanwhile, in the technical aspect, it tends to be top down, involving only the government and academicians. As a result, some materials of Bylaw cannot be accepted by street vendors. For example, the determination of red zones was conducted not through 
negotiation between street vendors and the government. As a consequence, street vendors feel that the determination of red zones is the effort of the government to eradicate street vendors and it does not consider the political, economic, and historical aspects of the region.

Meanwhile, from the aspect of the government, difficulties in the implementation of the policy of the arrangement of street vendors are caused by:

1. Incompatibility between the place for relocation and characteristics of street vendors. The policy on the Arrangement of Street Vendors which determines 283 points of red zones and imposes certain hours of operation in 217 points of yellow zones has made street vendors almost have no places in public space. However, on the other hand the government has the problems in providing places for relocation. Even if the government provides places for relocation, street vendors cannot easily accept them. It is because the places for relocation are considered not accessible to visitors, less strategic, and not appropriate to characteristics of wares they sold and lack of sufficient facilities.

2. The unpreparedness of the apparatus in implementing the policy on the arrangement of street vendors. One of the provisions contained in the policy on street vendors is the responsibility of street vendors to control street vendors in the red and yellow zones. In facts, the number of red zones which is not equaled by the quantity and quality of both resources and facilities owned by Civil Service Police Unit has made the activities of eviction and control cannot be conducted routinely every day. In addition, the implementation of the provision that imposing the fines to purchasers cannot consistently be conducted because there are no officers who routinely watch them and the mechanism of the fines has not yet been clear. Meanwhile, the presence of the Special Task Force which involves several technical institutions, such as boards and offices and also regional apparatus (heads of districts and subdistricts) is not equaled by effective coordination although tasks of each sector have been formulated in Mayoral Regulation.

3. The paradigm of integrated handling of street vendors has not yet been formulated in more technical development policies. The building of public facilities, such as sports field, parks, shopping centers, and offices will always be followed by the presence of street vendors. Characteristics of street vendors that always follow the formal sector must be responded by the government by preparing spaces for street vendors in every construction of public places.

4. The programs of eviction, arrangement, and supervision have not been wholly integrated. Activities of the arrangement of street vendors tend to be understood as soft eviction. It is because there is no sustainable program for street vendors who have been arranged, such as credit facilitation, improvement of business skills, and promotion of the places of relocation.

Explained that the failure of the policy on street vendors is due to the supply-side oriented approach applied by the government. In other words, the government continuously regulates, arrange, and help street vendors without conducting equal communication and cooperation with street vendors as the target group (demand side). Besides that, it is also identified that there has not yet been relatedness and coordination in the development of street vendors at the micro and macro levels [2].

In line with the research conducted by Sasono [2] observed that the failure of the policy on the development of the informal sector is caused by three main factors. The first, the characteristic of the issued provisions of the arrangement of the informal sector of street vendors is still fully decided by bureaucracy apparatus without listening to the affected parties, especially the informal sector itself. The second, the implementation of policies/programs intended to the informal sector is overly laden with the involvement of "supervising" apparatus. The third, the spirit of regulation to curb and to control the informal sector seems to be more dominant relating to the involvement of the government in the implementation of the project and it is lack of the spirit to develop the informal sector as one of the potentials in the development of the people's economy.

This study quite clearly depict the failure of the implementation of the policy on street vendors which is caused by some factors, among other things, the policy that does not sufficiently accommodate the interest of street vendors and socio-economic conditions within the business circle of street vendors.

Thus, the success of structuring street vendors will depend on the communication which is built between the government and street vendors. Technically, street vendor organizations clearly know the characteristics and problems in the field. This condition can be utilized by the government by collaborating to realize the zero growth of Istreet vendors, to obey the rules of zoning street vendors, and to do protection on street vendors. The diversity of street vendor categories which consists of self-contained street vendors, street vendors who are sellers with commissions, street vendors who are dependent workers [3] and "new-generation" street vendors which are from middle-class, highly educated and manage their businesses using adequate technology and skills business should be followed by different policies.

The policy of structuring street vendors in Bandung has set about the characteristics of street vendors as it is seen from the goods which are sold and the business facilities which are used. The reality in the field, the policy is not implemented effectively. For new-generation street vendors, they should be organized through informal policy by placing them in traditional markets or buildings that are not used anymore by imposing a certain amount of rent. Meanwhile, independent street vendors need to be given business protection for example by providing soft loans.

\section{CONCLUSION}

The policy on structuring street vendors still needs to be improved both at the level of policy content and policy implementation. In addition, it needs intensive communication 
between the government and street vendors to reach agreements on management of street vendors. The involvement street vendors in formulating and implementing the policy of street vendors will be the factors that determine the success of the implementation of structuring street vendor policy.

\section{REFERENCES}

[1] A.A.Mustafa, Ali. Social Transformation Models Informal Sector History, Theory and Praxis Street Merchants (Model Transformasi Sosial Sektor Informal Sejarah, Teori dan Praksis Pedagang Kaki Lima. Malang), In-Trans Publishing, 2008

[2] S.V. Sethurahman. "Urbanization and Employment in Jakarta". Geneva:ILO World Programme Research. 1974

[3] R. Ramli. "Urban Informal Sector: Street Traders in Jakarta" (Sektor Informal Perkotaan : Pedagang Kaki Lima di Jakarta). Ind-Hill Co, Jakarta. 1992 